УДК 656.629 (477+476)

JEL Classification L91

DOI 10.31375/2226-1915-2020-1-44-58

Л.А. Павловская к.э.н., доцент кафедры

«Управление логистическими системами и проектами»

Одесский национальный морской университет, Одесса, Украина

\section{МЕТОДИКА РАЗВИТИЯ}

РЕЧНЫХ ПЕРЕВОЗОК

НА НАПРАВЛЕНИИ «УКРАИНА-БЕЛОРУСЬ»

Аннотация. В статье рассмотрена актуальная задача реализации транзитного потенциала Украинь за счет развития речного транспортного коридора E-40 на украинско-белорусском участке.

Предложена методика обоснования проекта развития речных перевозок на направлении «Украина-Белоруссия», которая предусматривает следующие шаги: анализ грузопотоков в прямом и обратном направлениях и формирование схемы работы судов; исследование гидротехнических условий района плавания и определение требований по выбору типов судов; определение возможных типов судов для работы на заданном направлении; оченка ценовых предложений по продаже судов и формирование бюджета проекта по вариантам; выбор формы финансирования проекта; формирование вариантов проекта с учетом форм финансирования; комплексная оценка вариантов проекта по показателям эффективности; выбор приоритетного варианта проекта; сравнение стоимости доставки альтернативными видами транспорта.

Практическая реализачия предлагаемой методики рассмотрена на примере перевозки зерновых грузопотоков компании «Грейн-Трансшипмент» на схеме «Днепр-Мозырь-Днепр». Для освое ния заданного грузопотока рассмотрень варианты приобретения барже-буксирного состава и двух типов сухогрузных самоходных судов. Согласно результатам комплексной оченки по показателям проектного анализа (NPV, PI, IRR, PP) лучшим вариантом является использование барже-буксирного состава. На заключительном этапе проведень сравнительные расчеты стоимости доставки $1 \mathrm{~m}$ груза речным, железнодорожным $и$ автомобильным транспортом.

Расчеты показали, что для указанных размеров партии груза перевозка речным транспортом значительно дешевле, а предложенная методика позволяет получить адекватные резульmambl.

Ключевые слова: методика, речные перевозки, барже-буксирный состав, сухогрузные самоходные суда, малые глубины, проектный анализ.

\section{(С) Павловская Л.А., 2020}

\section{4}

УДК 656.629 (477+476)

JEL Classification L91

DOI 10.31375/2226-1915-2020-1-44-58

Л.А. Павловська

к.е.н., доцент кафедри «Управління логістичними системами і проектами» ORCID: 0000-0002-6856-7316

Одеський начіональний морський університет, Одеса, Украӥна

\section{МЕТОДИКА РОЗВИТКУ \\ РІЧКОВИХ ПЕРЕВЕЗЕНЬ}

НА НАПРЯМКУ «УКРАЇНА-БІЛОРУСЬ»

Анотація. У статті розглянута актуальна задача реалізачії транзитного потенціалу Украӥни за рахунок розвитку річкового транспортного коридору E-40 на украӥнсько-білоруській діляниі.

Запропонована методика обтрунтування проекту розвитку річкових перевезень на напрямку «Україна-Білорусь», яка трунтується на системному підході та передбачає використання методів статистичного та проектного аналізу. Задля апробації методики, що пропонується, проведені експериментальні розрахунки на конкретному прикладi: перевезення зернових вантажопотоків компанії "Грейн-Трансшипмент» на схемі «ДніпроМозир-Дніпро». Для освоєння заданого вантажопотоку з урахуванням наданих вантажів та обмежень 3 а осадкою розглянуті варіанти придбання можливих типів суден: баржебуксирного складу та двох типів суховантажних самохідних суден. Сформовано дев'ять можливих варіантів проекту. Відповідно до результатів комплексної оцінки за показниками проектного аналізу (NPV, PI, IRR, PP) крашим варіантом проекту є використання барже-буксирного складу. На завершальному етапі про-ведені порівняльні розрахунки вартості доставки $1 \mathrm{~m}$ вантажу річковим, залізничним та автомо-більним транспортом.

Розрахунки показали, щзо для вказаних розмірів партії вантажу перевезення річковим транспортом суттєво дешевще, а запропонована методика дозволяе отримати адекватні результати.

Ключові слова: методика, річкові перевезення, барже-буксирний склад, суховантажні самохідні судна, малі глибини, проектний аналіз. 
UDC $656.629(477+476)$

JEL Classification L91

DOI 10.31375/2226-1915-2020-1-44-58

L. Pavlovska

Ph.D., associate Professor of the Department of «Management of Logistics Systems and Projects»

ORCID: 0000-0002-6856-7316

Odessa National Maritime University, Odessa, Ukraine

\section{METHOD OF THE DEVELOPMENT OF RIVER FREIGHT TRANSPORTATIONS IN DIRECT «UKRAINE-BELARUS»}

Abstract. The article considers the urgent task of implementing transit transport routes E-40 on the Ukrainian-Belarusian section.

A methodology for substantiating a river transport development project along the Ukraine-Belarus direction is proposed, which provides for the following steps: analysis of cargo flows in the forward and reverse directions and formation of the scheme of work of ships; study of the hydraulic conditions of the navigation area and determination of requirements for the selection of ship types; identification of possible types of vessels for work in a given direction; evaluation of price proposals for the sale of ships and formation of the project budget for options; the choice of project financing form; formation of project options taking into account forms of financing; comprehensive assessment of project options by performance indicators; selection of a priority project option; comparison of shipping costs with alternative modes of transport.

The practical implementation of the proposed methodology is considered on the example of the transportation of grain cargo flows of the Grain-Transshipment company on the DneprMozyr-Dnepr scheme. Belarusian Sea Shipping Company and Grain-Transshipment company signed a memorandum of cooperation. It is agreed that with the start of river navigation on the Dnieper River, grain cargo will begin to be transported to one of the river ports in Belarus, and the Belarusian Sea Shipping Company will deliver fertilizers to the transshipment complex «Dnieper Pearl».

Taking into account the declared cargo transportation and draft restrictions on a given route, the barge-towing convoy and two types of self-propelled vessels (Nadezhda and Dneprovets) were considered in the work. According to the results of a comprehensive assessment of the indicators of project analysis (NPV, PI, IRR, PP), the best option is to use a barge-towing train. At the final stage, comparative calculations of the cost of delivering 1 ton of cargo by river, rail and road were carried out.

Calculations showed that for the indicated sizes of the consignment, transportation by river is much cheaper, and the proposed method allows us to obtain adequate results. The practical significance of the obtained results lies in the fact that they can be used to support decisionmaking on updating the Ukrainian river fleet.

Keywords: methods, river transport, towing barge, self-propelled dry cargo vessels, shallow depths, project analysis. 
DEVELOPMENT OF MANAGEMENT

AND ENTREPRENEURSHIP METHODS

ON TRANSPORT, № 1 (70), 2020
РОЗВИТОК МЕТОДІВ

УПРАВЛІННЯ ТА ГОСПОДАРЮВАННЯ

НА ТРАНСПОРТІ, № 1 (70), 2020

\section{Постановка проблемы.}

Рассмотрена актуальная задача реализации транзитного потенциала Украины за счет развития водного пути Е-40 (по маршруту ГданьскВаршава-Брест-Пинск-Мозырь-КиевХерсон), который существует на бумаге с 1996 года. Следует отметить, что от Варшавы до Бреста он не судоходный, поэтому планы по «восстановлению» Е-40 предполагают строительство обводного канала в Польше, ряда плотин и шлюзов на Припяти, а также дноуглубительные работы по всему маршруту для того, чтобы по рекам могли ходить крупнотоннажные суда класса «река-море».

В настоящее время доля использования внутреннего водного транспорта для транспортировки грузов в Польше, Беларуси и Украины очень мала и не превышает $1 \%$ (табл. 1). Вместе с тем, в период c 1970 по 1990 гг. доля таких перевозок была существенно выше. Это указывает на уже имеющийся потенциал развития и дает основания ожидать быстрого роста грузоперевозок водным транспортом в случае вложения инвестиций.

Таблий 1

Доля внутреннего судоходства

в грузовых перевозках в ЕС и странах вдоль водного пути E-40, \%

\begin{tabular}{|c|c|c|c|}
\hline Наименование & $\begin{array}{c}\text { Железная } \\
\text { дорога }\end{array}$ & $\begin{array}{c}\text { Автомобильные } \\
\text { дороги }\end{array}$ & $\begin{array}{c}\text { Внутреннее } \\
\text { судоходство }\end{array}$ \\
\hline ЕС (28 стран) & 17,80 & 75,40 & 6,70 \\
\hline Польша & 12,60 & 84,00 & 0,38 \\
\hline Украина & 24,12 & 68,48 & 0,23 \\
\hline Беларусь & 29,71 & 40,85 & 0,96 \\
\hline
\end{tabular}

Источник:[1]

Существует ряд основных проблем, сдерживающих развитие речных перевозок в Украине: недостаток базового законодательства для регулирования деятельности речного транспорта; отсутствие гибкой тарифной политики; неуклонное старение флота.

Кроме того, для развития речных перевозок на направлении «Украина-Беларусь» в рамках проекта E-40 необходимо, в первую очередь, выполнить дноуглубительные работы на перекатах Днепровского и Днепродзержинского водохранилищ и увеличить габариты водного пути на участке Киевская ГЭС-Нижние Жары.

Однако, важнейшей проблемой, которая сдерживает развитие речных перевозок в Украине, является устарелость большей части существующего флота.

Имеющийся потенциал речного флота Украины уменьшается из-за приближения значительной его 
РОЗВИТОК МЕТОДІВ

УПРАВЛНННЯ ТА ГОСПОДАРЮВАННЯ

НА ТРАНСПОРТІ, № 1 (70), 2020 части к критическому сроку эксплуатации. Обновление тоннажа требует больших капиталовложений. Сегодня государство не в силах самостоятельно решить задачу по возрождению торгового флота. Перспективным выглядит привлечение промышленнофинансовых групп, которые являются активными участниками интеграционных процессов и имеют опыт осуществления инвестиционных проектов.

Примером такой группы может служить компания «Грейн-
Транс-шипмент», в распоряжении которой находится речной терминал «Жемчужина Днепра» (г. Днепр). Компания занимается не только выращиванием и закупкой зерновых культур, но также обеспечивает элеваторное хранение и осуществляет последующую транспортировку грузов речным и автомобильным транспортом.

Компания «Грейн-Трансшипмент» оперирует десятью судами и занимается строительством собственного флота (табл. 2).

Таблица 2

Характеристика судов компании «Грейн-Трансшипмент»

\begin{tabular}{|c|c|c|c|c|c|c|}
\hline $\begin{array}{c}\text { Номер } \\
\text { п/п }\end{array}$ & $\begin{array}{c}\text { Наиме- } \\
\text { нование }\end{array}$ & БТ-418 & Алый & PLUTUS & ZEUS & Солегорск \\
\hline 1 & 2 & 3 & 4 & 5 & 6 & 7 \\
\hline 1. & Тип судна & $\begin{array}{c}\text { Буксир- } \\
\text { толкач }\end{array}$ & $\begin{array}{c}\text { Буксир - } \\
\text { кантов- } \\
\text { щик }\end{array}$ & $\begin{array}{c}\text { Буксир- } \\
\text { толкач } \\
\text { проекта } \\
809 / 3\end{array}$ & $\begin{array}{c}\text { Буксир- } \\
\text { толкач } \\
\text { проекта } \\
809 / 3\end{array}$ & $\begin{array}{c}\text { Сухо- } \\
\text { грузный } \\
\text { теплоход }\end{array}$ \\
\hline 2. & $\begin{array}{l}\text { Год } \\
\text { постройки }\end{array}$ & 1980 & 1977 & 1977 & 1977 & 1965 \\
\hline 3. & $\begin{array}{c}\text { Район } \\
\text { плавания }\end{array}$ & $\begin{array}{c}\text { ВВП высотой } \\
\text { волны не }\end{array}$ & $\begin{array}{c}\text { Черное } \\
\text { море, } \\
\text { река } \\
\text { более } 1,2 \text { м }\end{array}$ & $\begin{array}{c}\text { Дернопе } \\
\text { море, } \\
\text { река } \\
\text { Днепр }\end{array}$ & $\begin{array}{c}\text { Черное } \\
\text { море, } \\
\text { река }\end{array}$ & $\begin{array}{c}\text { Ворские райо- с высотой } \\
\text { волны } 2 \text { м }\end{array}$ \\
\hline 4. & $\begin{array}{c}\text { Автономн } \\
\text { ость, сут. }\end{array}$ & 5 & 10 & - & - & 10 \\
\hline 5. & Длина, м & 25,59 & 23,4 & 34,43 & 34,52 & 90 \\
\hline 6. & Ширина, м & 5,2 & 5,7 & 11,5 & 11,4 & 13 \\
\hline 7. & $\begin{array}{c}\text { Высота } \\
\text { борта, м }\end{array}$ & 2,4 & 2,6 & 2,8 & 2,8 & 4,8 \\
\hline 8. & $\begin{array}{c}\text { Осадка } \\
\text { тах, м }\end{array}$ & 0,91 & 1,88 & 2 & 2 & 3,32 \\
\hline 9. & $\begin{array}{c}\text { Скорость } \\
\text { тах, узлы }\end{array}$ & 6 & 8 & 12 & 12 & 7 \\
\hline 10. & GRT, рег. т & 77,4 & 69 & 379,82 & 378,46 & 1659 \\
\hline
\end{tabular}


Продолжение табл. 2

\begin{tabular}{|c|c|c|c|c|c|c|}
\hline 1 & 2 & 3 & 4 & 5 & 6 & 7 \\
\hline 11. & $\begin{array}{c}\text { Дедвейт } \\
\text { тах, т }\end{array}$ & 8,91 & 15 & 64,34 & 126,5 & 2606,9 \\
\hline 12. & $\begin{array}{c}\text { Количество } \\
\text { экипажа, чел. }\end{array}$ & 2 & 4 & 8 & 8 & 9 \\
\hline 13. & $\begin{array}{c}\text { Гл. двигатель, } \\
\text { ед./kWt }\end{array}$ & $1 / 220$ & $1 / 232$ & $\begin{array}{c}\text { Two diesel, } \\
1766 \mathrm{kWt}\end{array}$ & $\begin{array}{c}\text { Two diesel, } \\
1766 \mathrm{kWt}\end{array}$ & $1 / 588$ \\
\hline 14. & $\begin{array}{c}\text { Затраты } \\
\text { топлива } \\
\text { л/час. }\end{array}$ & 40 & 48 & $250-300$ & $250-300$ & $83 / 61$ \\
\hline
\end{tabular}

Источник: [2]

«Белорусское морское пароходство» и компания «Грейн-Трансшипмент» подписали меморандум о сотрудничестве. Есть договоренность, что с началом речной навигации на реке Днепр начнется перевозка зерновых грузов в один из речных портов в Беларусь, а «Белорусское морское пароходство» будет осуществлять доставку удобрений на перегрузочный комплекс «Жемчужина Днепра» (рис.1) [3].

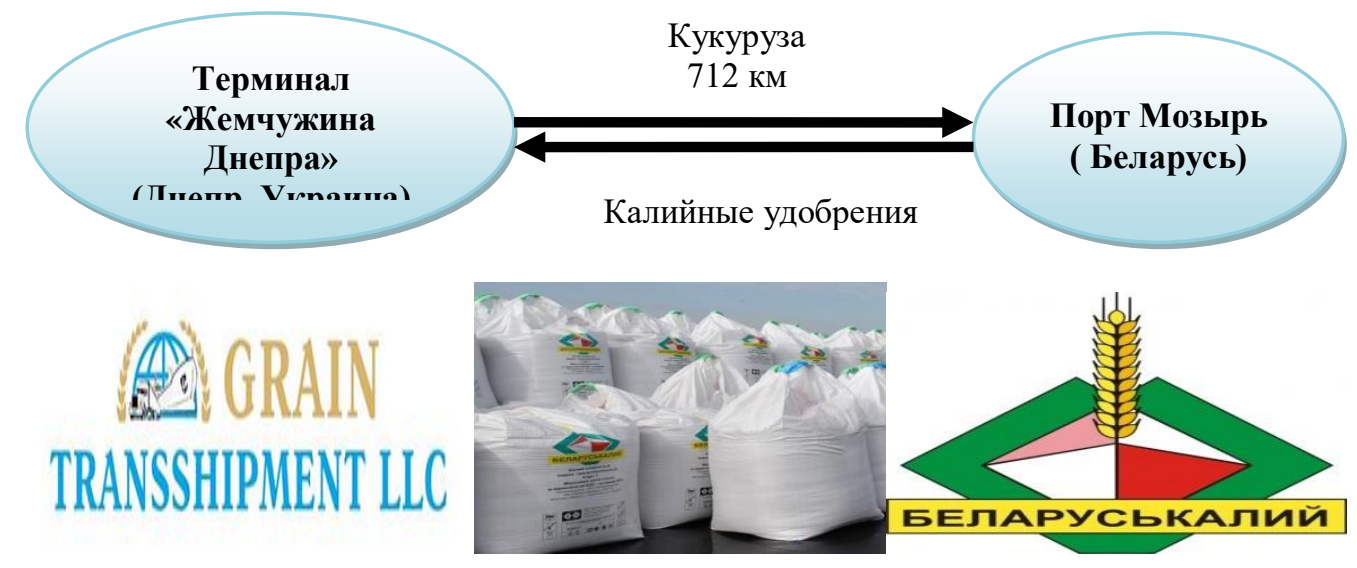

Рис. 1. Схема работы судов «Днепр-Мозырь-Днепр»

Источник: разработка автора на основе [3] 
Восстановление судоходства на Припяти является одним из приоритетов Национальной транспортной стратегии Украины до 2030 года, потому как позволит раскрыть транзитный потенциал Украины за счет развития речного транспортного коридора Е-40 от Балтийского до Черного моря.

Обзор последних исследований и публикаций. Анализ исследований и публикаций по данной тематике позволяет сделать вывод об их незначительном количестве.

В публикациях [4; 5] рассматриваются актуальные проблемы реализации транспортного потенциала внутренних водных путей Польши.

Достаточно много публикаций посвящено развитию речных перевозок на реках Волжского и Сибирского регионов.

Так, например, в работе [6] рассматривается роль водного транспорта в развитии прямых смешанных сообщений, подчеркивается его перспективность и востребованность.

Среди отечественных авторов следует отметить работу [7], посвященную Дунайскому региону, а также работу [8], рассматривающую вопросы организации работы баржебук-сирных составов.

В публикациях $[9 ; 10 ; 11]$ относительно развития речных перевозок на украинско-белорусском направлении отмечается его актуальность. Публикации касаются в основном перечня существующих проблем, без оценки комплексного варианта их решения.

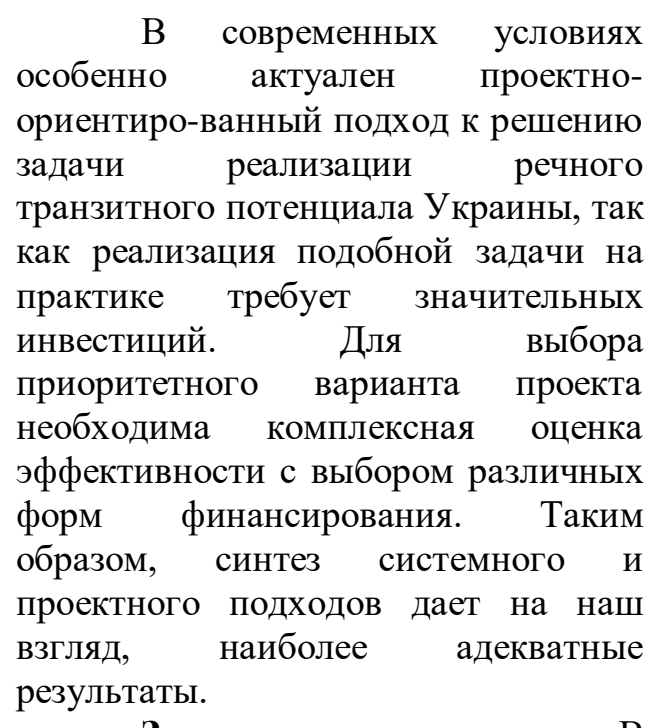

Задачи исследования. В работе рассмотрено современное состояние магистрального водного пути Е-40. Выявлен круг проблем, требующий немедленного решения. Основная цель исследования повышение эффективности речных перевозок в направлении «УкраинаБеларусь путем разработки методики обоснования проекта развития речных перевозок отечественным флотом.

Основной материал исследования. Предлагается методика обоснования проекта развития речных перевозок на направлении «Украина-Беларусь», которая включает в себя девять последовательных этапов (рис. 2). Поскольку на участке p. Днепр выше Киева и далее на p. Припять до Мозыря глубины составляют не более 1,6 м, возникает вопрос в выборе таких проектных 
вариантов судов, осадка которых не превышает эту величину (табл. 3). При этом эти суда должны иметь закрытые трюма для перевозки

зерновых грузов.

Шаг 1. Анализ грузопотоков в прямом и обратном направлениях и формирование схемы работы судов

\begin{tabular}{l} 
Шаг 2. Исследование гидротехнических условий района плавания \\
и определение требований по выбору типов судов \\
Шаг 3. Определение возможных типов судов \\
для работы на заданном направлении \\
\hline Шаг 4. Оценка ценовых предложений по продаже судов \\
и формирование бюджета проекта по вариантам \\
\hline
\end{tabular}

Шаг 5. Выбор формы финансирования проекта

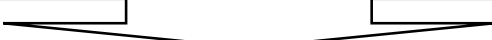

Шаг 6. Формирование вариантов проекта

с учетом форм финансирования

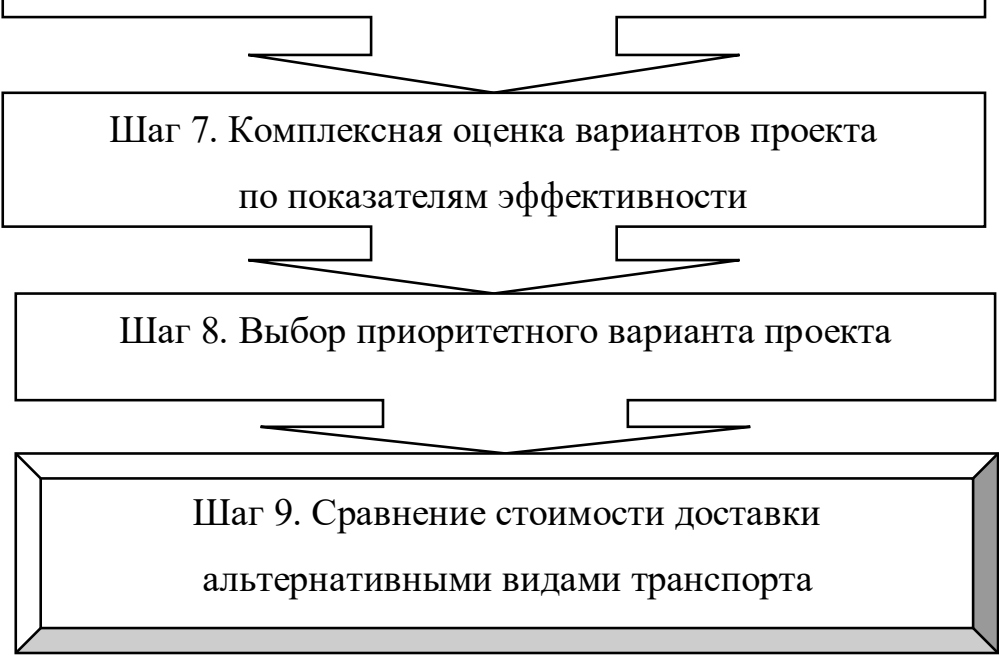


Рис. 2. Алгоритм обоснования

проекта развития речных перевозок на направлении «Украина-Беларусь»

Источник: разработка автора

Таблийа 3

Характеристики украинских и белорусских участков коридора E-40

\begin{tabular}{|c|c|c|c|c|c|c|c|c|c|c|c|c|c|}
\hline \multirow[t]{2}{*}{ Показатель } & 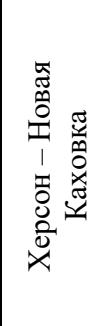 & 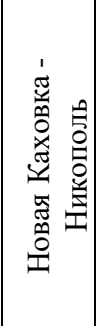 & 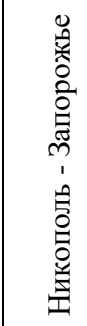 & 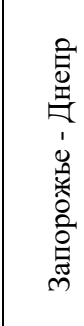 & 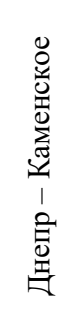 & 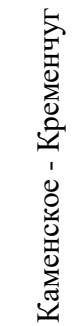 & 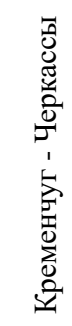 & 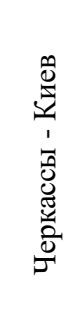 & 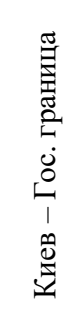 & 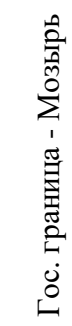 & 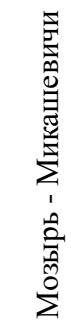 & 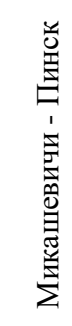 & \multirow[t]{2}{*}{ 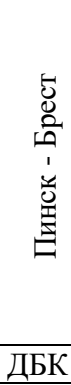 } \\
\hline & \multicolumn{9}{|c|}{ река Днепр } & \multicolumn{3}{|c|}{ река Припять } & \\
\hline Длина, км & 68 & 128 & 84 & 85 & 36 & 123 & 100 & 200 & 146 & 107 & 235 & 115 & 194 \\
\hline $\begin{array}{l}\text { Мини- } \\
\text { мальная } \\
\text { глубина, м }\end{array}$ & 3,65 & 3,65 & 3,65 & 3,0 & 3,65 & 3,65 & 3,65 & 3,65 & 1,6 & 1,6 & 1,45 & 1,5 & 2,0 \\
\hline $\begin{array}{l}\text { Минималь } \\
\text { ная высота } \\
\text { под } \\
\text { мостами, м }\end{array}$ & 17,2 & 22,6 & 22,6 & 14,7 & - & - & 13,2 & 13,2 & - & 7,63 & 7,52 & 8,95 & 8,6 \\
\hline $\begin{array}{l}\text { Количество } \\
\text { шлюзов }\end{array}$ & 1 & 0 & 0 & 1 & 1 & 1 & 0 & 2 & 0 & 0 & 0 & 2 & 9 \\
\hline $\begin{array}{l}\text { Общее } \\
\text { количество } \\
\text { судов }\end{array}$ & 28 & 07 & & 72 & & 583 & 624 & 542 & 1070 & Н. д. & Н. д. & 70 & 119 \\
\hline $\begin{array}{l}\text { Количество } \\
\text { грузовых } \\
\text { судов }\end{array}$ & 20 & 72 & & 33 & & 52 & 187 & 122 & 59 & Н. д. & Н. д. & н. д. & н. д. \\
\hline
\end{tabular}

Источник: [1]

Выполнить оба эти условия оказалось не так просто. Как правило, современные речные суда с такой малой осадкой - это самоходные сухогрузные суда-площадки-толкачи. Однако, такие суда, например, суда проекта RD63 (разработка «Морского инженерного бюро») предназначены для перевозки генеральных и навалочных грузов, не боящихся воздействия окружающей среды, включая 20-ти и 40-ка футовые контейнеры международного стандарта, металл и металлопродукцию, лес, бревна и пиломатериалы, уголь, строительные материалы, крупногабаритные грузы и толкание сухогрузных и наливных барж по ВВП [12]. 
РОЗВИТОК МЕТОДІВ

УПРАВЛНННЯ ТА ГОСПОДАРЮВАННЯ

НА ТРАНСПОРТІ, № 1 (70), 2020
Поэтому далее мы исходили из наличного флота компаний инициаторов проекта, и существующих проектов речных судов с малой осадкой и закрытыми трюмами.

Таким образом, с учетом заявленных к перевозке грузов и ограничений по осадке на заданном маршруте в работе рассмотрены следующие типы судов (табл. 4):

- барже-буксирный состав буксир-толкач БТ-418 и баржеплощадка «Grain-1», судовладелец компания «Грейн-Трансшипмент» (рис. 3);
- самоходный сухогрузный теплоход-площадка «Надежда» (проект 775), судовладелец «Белорусское морское пароходство» (рис. 4);

- самоходное судно типа СТ проекта Р-168 - «Днепровец», судовладелец компания «Укрречфлот» (рис. 5).

Для каждого из выбранных типов судов было рассмотрено несколько возможных вариантов эксплуатации, в зависимости от периода эксплуатации, формы финансиро-вания и условий продажи судна (табл. 5).

Таблицча 4

Основные характеристики типов судов, рассматриваемые в проекте

\begin{tabular}{|c|c|c|c|c|}
\hline \begin{tabular}{|c|} 
Hoмep \\
$\Pi / \Pi$ \\
\end{tabular} & Наименование & ББС & T/x «Надежда» & T/x «Днепровец» \\
\hline 1. & Тип судна & $\begin{array}{c}\text { Буксир-толкач } \\
\text { БТ-418 и } \\
\text { барже- } \\
\text { площадка } \\
\text { «Grain-1» }\end{array}$ & $\begin{array}{c}\text { Самоходный } \\
\text { сухогрузный } \\
\text { теплоход }\end{array}$ & $\begin{array}{c}\text { Самоходный } \\
\text { сухогрузный } \\
\text { теплоход }\end{array}$ \\
\hline 2. & Длина, м & 98,59 & 73,8 & 84,0 \\
\hline 3. & Ширина, м & 12,0 & 12,21 & 12,3 \\
\hline 4. & Высота борта, м & 2,4 & 7,13 & 3,5 \\
\hline 5. & Осадка max, м & 1,8 & 1,87 & 1,6 \\
\hline 6. & $\begin{array}{l}\text { Скорость с грузом, } \\
\text { км/час }\end{array}$ & 11,0 & 15,5 & 18,0 \\
\hline 7. & Грузоподъемность, т & 1000 & 725 & 625 \\
\hline 8. & $\begin{array}{l}\text { Количество экипажа, } \\
\text { чел. }\end{array}$ & 2 & 8 & 9 \\
\hline 9. & $\begin{array}{l}\text { Гл. двигатель, } \\
\text { ед./kWt }\end{array}$ & $1 / 220$ & $2 \times 220$ & $2 \times 440$ \\
\hline
\end{tabular}


DEVELOPMENT OF MANAGEMENT AND ENTREPRENEURSHIP METHODS ON TRANSPORT, № 1 (70), 2020
РОЗВИТОК МЕТОДІВ УПРАВЛІННЯ ТА ГОСПОДАРЮВАННЯ НА ТРАНСПОРТІ, № 1 (70), 2020

Источник: [2; 13; 14]

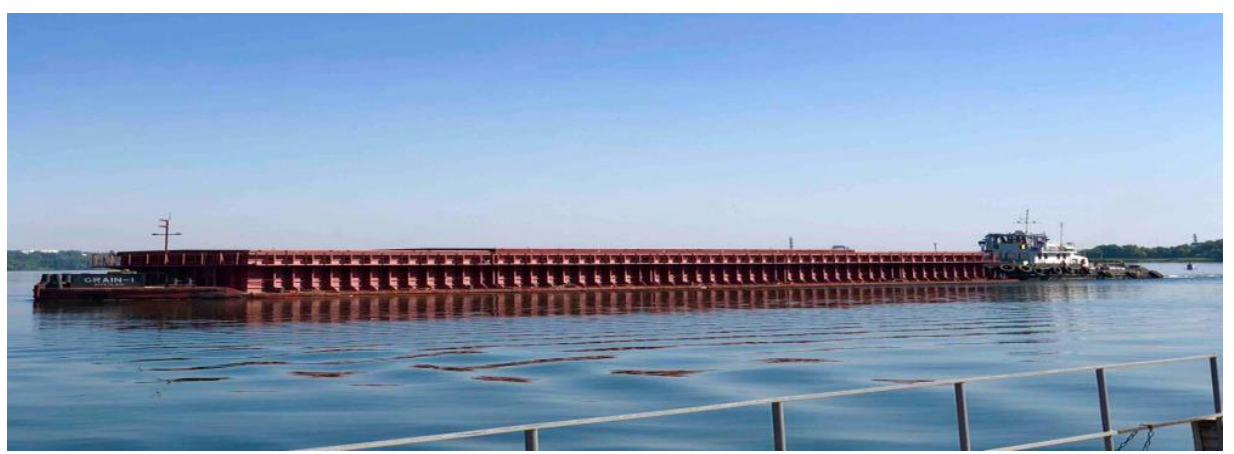

Рис. 3. Буксир-толкач БТ-418 и барже-площадка «Grain-1»

Источник: [2]

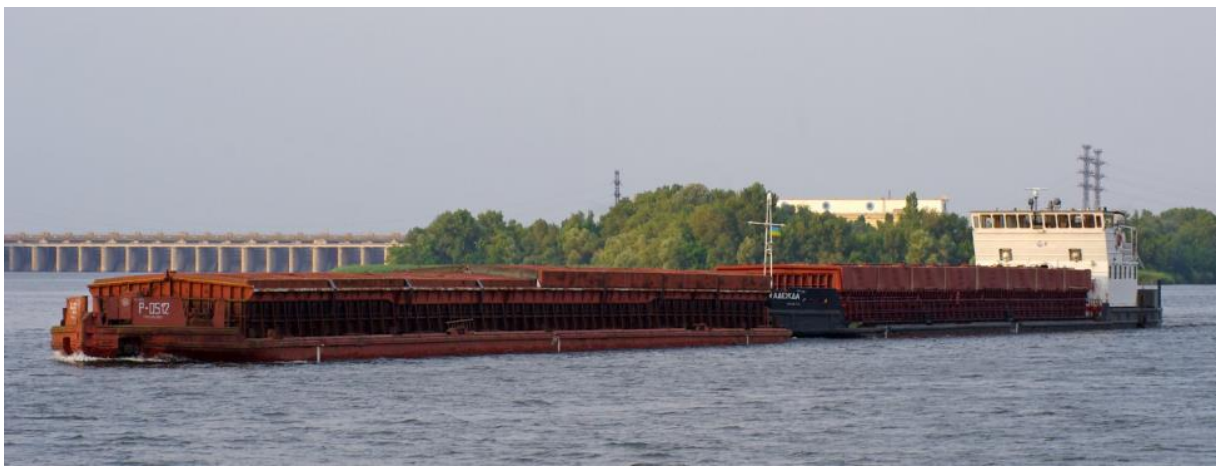

Рис. 4. Самоходный сухогрузный теплоход-площадка «Надежда»

Источник: [13]

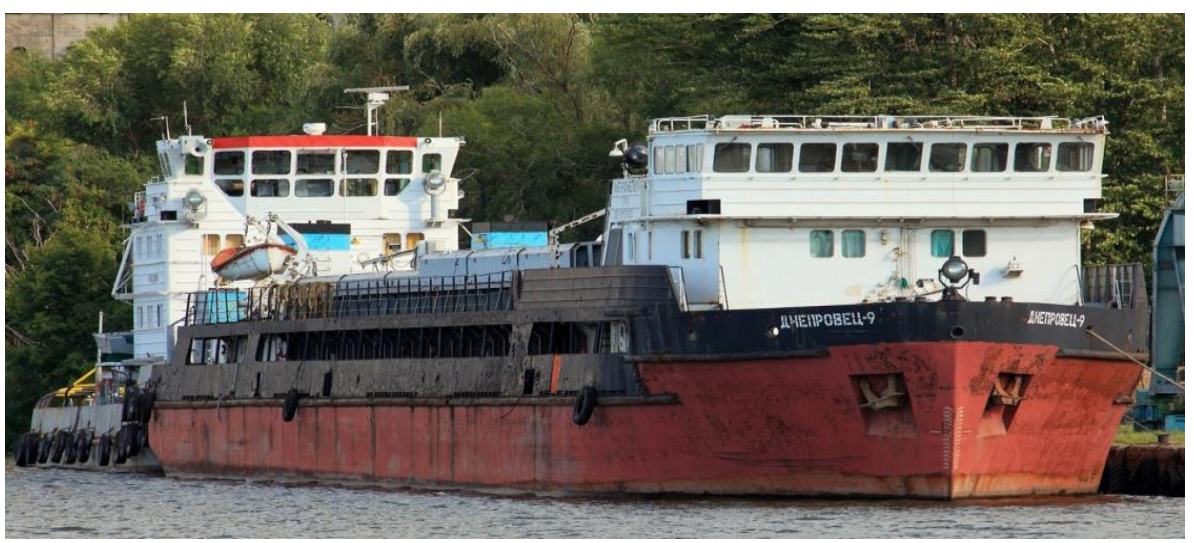

Рис. 5. Самоходное сухогрузное судно типа СТ проект Р-168 - «Днепровеиฺ» 
Источник: [14]

Таблица 5

Рассматриваемые варианты проекта

\begin{tabular}{|c|c|}
\hline Тип судна & Вариант проекта \\
\hline \multirow{2}{*}{$\begin{array}{c}\text { Буксир-толкач БТ-418 (1980 г. п.) } \\
\text { и барже-площадка «Grain-1» } \\
\text { (модернизация } 2019 \text { г.) }\end{array}$} & $\begin{array}{c}\text { Эксплуатация на протяжении } 10 \text { лет } \\
\text { (внутреннее финансирование) }\end{array}$ \\
\cline { 2 - 2 } & $\begin{array}{c}\text { Эксплуатация на протяжении 5 лет } \\
\text { с продажей (внутреннее финансирование) }\end{array}$ \\
\hline \multirow{2}{\text{Самоходное}}{$\begin{array}{c}\text { Эксплуатация на протяжении } 15 \text { лет } \\
\text { (внутреннее финансирование) }\end{array}$} \\
\cline { 2 - 2 } $\begin{array}{c}\text { сухогрузное судно «Надежда» } \\
\text { (2012 г. п.) }\end{array}$ & $\begin{array}{c}\text { Эксплуатация на протяжении } 10 \text { лет } \\
\text { с продажей (внутреннее финансирование) }\end{array}$ \\
\cline { 2 - 2 } $\begin{array}{c}\text { Самоходное } \\
\text { Эксплуатация на протяжении 5 лет } \\
\text { сухогрузное судно «Днепровец» } \\
\text { (1992 г. п.) }\end{array}$ & $\begin{array}{c}\text { Эксплуатация на протяжении 5 лет } \\
\text { (внутреннее финансирование) }\end{array}$ \\
\hline
\end{tabular}

Источник: разработка автора

Каждый из вариантов проекта был оценен комплексно по показателям: чистой современной стоимости (NPV), индексу доходности (PI), внутренней нормы прибыльности (IRR), сроку окупаемости проекта (PP) [14]. Учитывая, что перечисленные показатели оценивают проект с разных сторон, проведена комплексная оценка полученных значений показателей методом суммы мест (табл. 6).

По результатам комплексной оценки лучшим вариантом является приобретение барже-буксирного состава с последующей его эксплуатацией в течение 10 лет (финансирование проекта внутреннее).
В сравнении с сухогрузными самоходными судами:

1. Буксир имеет меньше затрат на содержание экипажа и топливо.

2. Грузоподъемность модернизированной барже-площадки больше, чем у самоходных судов. Баржа «Grain-1» прошла модернизацию в 2019 году на судоремонтном предприятии «Дунайсудсервис» (г. Из-маил), в том числе была дооборудована съемными брызгонепроницае-мыми люковыми крышками для возможности перевозки зерна.

На заключительном этапе проведены сравнительные расчеты стоимости доставки 1 т груза речным, 
железнодорожным и автомобильным транспортом (табл. 7). Расчеты показали, что для указанных размеров партии груза перевозка речным транспортом значительно дешевле.

Таблица 6

Комплексная оценка

показателей эффективности по вариантам проекта методом суммы мест

\begin{tabular}{|c|c|c|c|c|c|c|c|c|c|c|}
\hline \multirow{3}{*}{ 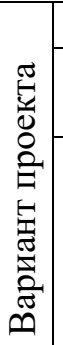 } & \multicolumn{8}{|c|}{ Показатели оценки эффективности } & \multirow{3}{*}{ 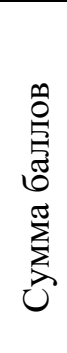 } & \\
\hline & \multicolumn{2}{|c|}{ NPV', тыс. долл. США } & \multicolumn{2}{|c|}{ PI } & \multicolumn{2}{|c|}{ РР, года } & \multicolumn{2}{|c|}{ IRR, \% } & & \\
\hline & 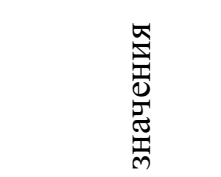 & స్త్రి & 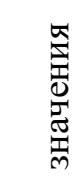 & క్ & 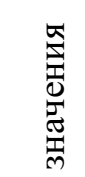 & $\begin{array}{l}5 \\
\text { క్ }\end{array}$ & 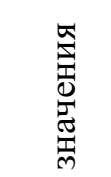 & $\begin{array}{l}\text { క్ } \\
\text { డ్ర }\end{array}$ & & $\sum^{a}$ \\
\hline 1 & $299090^{\circ}$ & 2 & 5,72 & 1 & 1,16 & 1 & 94,91 & 1 & 5 & 1 \\
\hline 2 & 3 & 1 & 4 & 2 & 1 , & 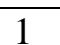 & 7 & 2 & 6 & 2 \\
\hline 3 & 906831 & 5 & 2,75 & 3 & 2,78 & 2 & 40,45 & 3 & 13 & 3 \\
\hline 4 & 965219 & 4 & 2,50 & 4 & 2,78 & 2 & 40,14 & 4 & 14 & 4 \\
\hline 5 & 1031626 & 3 & 1,99 & 5 & 2,78 & 2 & 39,18 & 5 & 15 & 5 \\
\hline 6 & 89129 & 6 & 1,11 & 6 & 4,26 & 3 & 14,55 & 6 & 21 & 6 \\
\hline
\end{tabular}

Источник: разработка автора на основе [15]

Таблииа 7

Стоимость доставки Im груза на направлении «Украина-Беларусь», долл./m

\begin{tabular}{|c|c|c|}
\hline \multirow{2}{*}{ Вид транспорта } & \multicolumn{2}{|c|}{ Направление перевозок } \\
\cline { 2 - 3 } & $\begin{array}{c}\text { Днепр-Мозырь } \\
\text { (кукуруза) }\end{array}$ & $\begin{array}{c}\text { Мозырь-Днепр } \\
\text { (удобрения) }\end{array}$ \\
\hline Речной & 12,5 & 10,5 \\
\hline Железнодорожный & 13,55 & 12,10 \\
\hline Автомобильный & 44,3 & 45,3 \\
\hline
\end{tabular}

Источник: разработка автора

Министерство инфраструктуры Украины высказало заинтересованность в наращивании объемов речных перевозок на Беларусь и подтвердило готовность выполнения дноуглубительных работ при наличии соответствующего грузопотока. Как видим, грузопотоки есть, флот тоже, осталось дело за малым - обеспечить необходимые глубины на р. Припять. 
Выводы. П Практическое

значение полученных результатов заключается в том, что они могут быть использованы для поддержки принятия решений по обновлению речного флота Украины.

\section{СПИСОК ЛІТЕРАТУРИ}

1. Від Чорного до Балтійського моря: перспективі відновлення магістрального водного шляху Е-40 на річках Польщі, Білорусі й України // Комісія з питань розвитку воднотранспортного сполучення Е-40 на ділянці Дніпро - Висла: Брошура. Мінськ: ТОВ «ТМ АГРО-ГРАФІКС», 2007. 37 c.

2. Сайт компании «Грейн-Транстипмент». URL: http://grain-transshipment.com/

3. «Грейн-Трансшипмент» начнет возить грузы из Беларуси [Электронный pecypc]. URL: https://ports.com.ua/news/greyn-transshipment-nachnet-vozit-gruzyiz-belarusi

4. Kotowska I., Mańkowska M., Pluciński M. The Competitiveness of Inland Shipping in Serving the Hinterland of the Seaports: A Case Study of the Oder Waterway and the Szczecin-Świnoujście Port Complex // In: Sierpiński G. (eds) Integration as Solution for Advanced Smart Urban Transport Systems. TSTP 2018. Advances in Intelligent Systems and Computing, 2019, vol. 844. Springer, Cham. PP.252-263

5. Miklinska J. Public private partnership projects for the development of Polish inland waterways. 39th International Scientific Conference on Economic and Social Development. Lisbon, 29-30 April 2019. PP.351-360

6. Пантина Т.А. Развитие перевозок в прямом смешанном сообщении с участием внутреннего водного транспорта: проблемы и возможности // Сб. научн. трудов XVIII Международной научно-практической конференции: «Логистика: современные тенденции развития». Санкт-Петербург, 04-05 Апрель, 2019. С. 33-39

7. Морозова И.В., Суворова Л.П. Перспективы украинского флота в перевозках по внутренним водным путям Европы. Одеса: ОНМУ, 2005. 192 c.

8. Щербіна О.В. Організація роботи баржебуксирних суден у транспортнотехнологічній системі: дис. ... канд. техн. наук 05.22.01. Одеса: ОНМУ, 2019. $217 \mathrm{c}$.

9. Скичко Ю. Транспортировку зерна по реке сдерживают логистические проблемы // Порты Украины. № 10. 2019. С.13-14

10. Гераменко А. Из варяг в греки // Порты Украины. №10. 2018. С.42-43

11. Ильниџкий К. Водники Беларуси потянулись к морю // Порты Украины. №9. 2019. C.16-18

12. Сайт «Морское инженерное бюро». URL: http://meb.com.ua/about.html

13. Сайт «Белорусское речное пароходство».

$U R L:$ http://www.parohodstvo.by/flot/95065.html

14. Сайт «Водный транспорт». URL: https://fleetphoto.ru/projects/268

15. Лапкина И.А., Павловская Л.А., Болдырева Т.В., Шутенко Т.Н. Проектный анализ: теоретические основы оченки проектов на морском транспорте: Учебное пособие. Одесса: Феникс, 2008. 416 c. 


\section{REFERENCES}

1. Vid Chornogo do Baltiyskogo morya: perspectivy vidnovlennya magistralnogo vodnogo shlyahu E-40 na richkax Polshi, Bilorusi i Ukrainy (2007). [From the Black Sea to the Baltic Sea: the prospect of restoration of the E-40 main waterway on the rivers of Poland, Belarus and Ukraine] // Comisiya z pytan rozvytku vodnotransportnogo spoluchennya E-40 na dilyanci Dnipro - Visla: Broshura. Minsk: TOV «TM AGRO-GRAFIKS», 37 [in Ukraine].

2. Sait «Grain-Transshipment». Retrieved from http://grain-transshipment.com/

3. «Grain-Transshipment » nachnet vozit gruzy iz Belarusi [Grain-Transshipment will begin to carry goods from Belarus]. Retrieved from https://ports.com.ua/news/greyntransshipment-nachnet-vozit-gruzy-iz-belarusi

4. Kotowska, I., Mańkowska, M. \& Pluciński, M. (2019). The Competitiveness of Inland Shipping in Serving the Hinterland of the Seaports: A Case Study of the Oder Waterway and the Szczecin-Świnoujście Port Complex // In: Sierpiński G. (eds) Integration as Solution for Advanced Smart Urban Transport Systems. TSTP 2018. Advances in Intelligent Systems and Computing, vol 844. Springer, Cham, 252263.

5. Miklinska, J. (2019). Public private partnership projects for the development of Polish inland waterways. 39th International Scientific Conference on Economic and Social Development. Lisbon, 29-30 April, 351-360.

6. Pantina, T.A (2019). Razvitie perevozok v pryamom smeshanom soobshenii s uchastiem vnutrennego vodnogo transporta: problemy $i$ vozmognosti [The development of transport in direct mixed traffic involving inland water transport: problems and challenges]. Sb. nauchn. trudov XVIII Mezhdunarodnoi nauchno-practicheskoi conferencii «Logistica: sovremennye tendencii razvitiya». Sankt-Peterburg, 04-05 Aprel, 33-39 [in Russian].

7. Morozova, I.V. \& Suvorova, L.P. (2005). Perspectivy ukrainskogo flota v perevozkax po vnutrennim vodnym putyam Evropy [Prospects of the Ukrainian fleet in transportations on inland waterways of Europe]. Odessa: ONMU, 192 [in Russian].

8. Sherbina, O.V. (2019). Organizaciya roboty barzhe buksirnyx suden u transportnotexnologichniy systemi [Organization of work of tow barges in the transport and technological system]: dis. ... kand. tehn. nauk 05.22.01. Odesa: ONMU, 217 [in Ukraine].

9. Skichko, Y. (2019). Transportirovku zerna po reke sderzhivayut logisticheskie problem [Logistics problems hinder grain transportation by river]. Porty Ukrainy - Ports of Ukraine, № 10, 13-14 [in Russian].

10. Gerashenko, A. (2018). Iz varyag v greki [From Varangians to Greeks]. Porty Ukrainy - Ports of Ukraine, №10, 42-43 [in Russian].

11. Ilnickiy, K. (2019). Vodniki Belarusi potyanulis $k$ moryu [Watermen of Belarus reached the sea]. Porty Ukrainy - Ports of Ukraine, №9, 16-18 [in Russian].

12. Sait «Marine Engineering Bureau». Retrieved from http://meb.com.ua/about.html [in Russian].

13. Sait «Belarusian River Shipping Company». Retrieved from http://www. parohodstvo.by/flot/95065.html [in Russian]. 
14. Sait «Water transport». Retrieved from https://fleetphoto.ru/projects/268

15. Lapkina, I.O., Pavlovskaya, L.A., Boldyreva, T.V. \& Shutenko, T.N. (2008). Proektniy analiz: teoreticheskie osnovy ocenki proektov na morskom transporte [Project analysis: theoretical foundations for evaluating projects in maritime transport]. Odessa: Feniks, 416 [in Russian].

Стаття надійшла до редакиії 17.02.2020

Посилання на статтю: Павловская Л.А. Методика развития речных перевозок на направлении «Украина-Белорусь» // Розвиток методів управління та господарювання на транспорті: Зб. наук. праць, 2020. № 1 (70). C. 44-58. DOI 10.31375/2226-1915-2020-1-44-58.

Article received 17.02.2020

Reference a JournalArtic: Pavlovska, L. (2020). Method of the development of river freight transportations in direct «Ukraine - Belarus». Development of management and entrepreneurship methods on transport. 1 (70), 44-58. DOI 10.31375/2226-1915-2020-1-44-58. 